ОБЩИЕ ВОПРОСЫ АВТОМОБИЛЬНОГО ТРАНСПОРТА

УДК 621.318 .4

\title{
ANALYSIS OF NONMAGNETIC METAL INDUCTION HEATING PROCESSES BY FLAT-TYPE CIRCULAR SOLENOIDAL FIELD
}

Yu. Batygin, Prof. D. Sc. (Eng.), E. Chaplygin, Assoc. Prof., Ph. D. (Eng.), M. Barbashova, Asst. Prof., Ph. D. (Eng.), S. Shinderuk, Asst. Prof., Ph. D. (Eng.),

T. Gavrilova, Assoc. Prof., Ph. D. (Fis.-Mat.), Kharkov National Automobile and Highway University

\begin{abstract}
The article analyzes the electromagnetic processes in the system of induction heating with estimating the main characteristics of heating the non-magnetic sheet metal. The analytical expressions for numerical estimates of the induced current in terms of the phase of the excitation signal are presented. The dependence for the heating temperature of the considered circular sheet metal area for the time corresponding to the interval phase has been determined.
\end{abstract}

Key words: induction heating, induction system, induced current, electromagnetic processes, eddy currents, metal heating, temperature dependence.

\section{АНАЛИЗ ПРОЦЕССОВ ИНДУКЦИОННОГО НАГРЕВА НЕМАГНИТНЫХ МЕТАЛЛОВ ПОЛЕМ ПЛОСКОГО КРУГОВОГО СОЛЕНОИДА}

Ю.В. Батыгин, проф., д.т.н., Е.А. Чаплыгин, доц., к.т.н., М.В. Барбашова, ст. преп., к.т.н., С.А. Шиндерук, ст. преп., к.т.н., Т.В. Гаврилова, доц., к.ф.-.м.н., Харьковский национальный автомобильно-дорожный университет

Аннотация. Проведен анализ электромагнитных процессов в системе индукиионного нагрева немагнитных листовых металлов. Представлены аналитические выражения для численных оценок индуцированного тока в терминах фазы возбуждающего сигнала. Определена зависимость для температуры нагрева рассматриваемой круговой области.

Ключевые слова: индукиионный нагрев, индукторная система, вихревые токи.

\section{АНАЛІЗ ПРОЦЕСІВ ІНДУКЦИЙНОГО НАГРІВАННЯ НЕМАГНІТНИХ МЕТАЛІВ ПОЛЕМ ПЛОСКОГО КРУГОВОГО СОЛЕНОЇДА}

\author{
Ю.В. Батигін, проф., д.т.н., С.О. Чаплигін, доц., к.т.Н., М.В. Барбашова, ст. викл., \\ к.т.н., С.О. Шиндерук, ст. викл., К.т.н., Т.В. Гаврилова, доц., к.ф.-.М.н., \\ Харківський національний автомобільно-дорожній университет
}

Анотація. Проведено аналіз електромагнітних процесів у системі індукиійного нагрівання немагнітних листових металів. Подано аналітичні вирази для чисельних оцінок індукованого струму в термінах фази збуджувального сигналу. Визначено залежність для температури нагрівання кругової області, щео розглядається.

Ключові слова: індукиійне нагрівання, індукторна система, вихрові струми.

Introduction

Induction heating $(\mathrm{IH})$ is heating metal objects by induced electrical currents (Foucault cur- rents). Induced currents are induced by an alternating magnetic solenoid field. Their flow is accompanied by the release of Joule-Lenz heat, which leads to the metal object heating [1-4]. 


\section{Analysis of publications}

Among the recent papers studied $\mathrm{IH}$ we should mention those describing in details the processes in the generators of transverse magnetic field [5], and summarizing the results of complex researches presented both in Russian and foreign publications, which describe methods for evaluating the integral characteristics of heating processes and the results of physical experiments in the production units [6].

The interest to IH exists in vehicle repair technologies, namely in removing glass, cleaning paintand-lacquer coating, disconnecting bolt joints, softening the metal coating of the body before removing dents, etc. [7].

The idea of using induction pre-heating in magnetic-pulse metal working was suggested in 1980s [8]. The researchers developed and created a system of initiation of current flow in the coil of the working tool by the moment of force impact. Induction heating allowed to increase enough the effective magnetic pulse deformation as a whole.

Following the logic of the first statement of the authors [8] positive results can be expected when using $\mathrm{IH}$ in the processing operations of pulsed magnetic attraction of preselected sections of the thin metal, especially in operations of eliminating the external dents on body elements [7, 9-11].

\section{Purpose and problem statement}

Theoretical analysis of electromagnetic processes in the system for induction heating, with the estimation of the main characteristics of heating the non-magnetic sheet metal by the field of flattype circular multiturn solenoid.

\section{The calculated ratio}

The estimated model in a cylindrical coordinate system with the guide unit vectors $\boldsymbol{e}_{r}, \boldsymbol{e}_{\varphi}, \boldsymbol{e}_{z}$ is presented in Fig. 1, a. The heating of a circular part of a sheet sample directly below the inductor radius coil $-R_{2}$, thickness $-d$ from metal with electrical conductivity $-\gamma$ and density $-\rho$ is studied.

We will rewrite the results cited in [12, 13], where the electromagnetic processes are studied in the system similar to the one describe above but with a single-loop inductor, in a form convenient for numerical estimates.

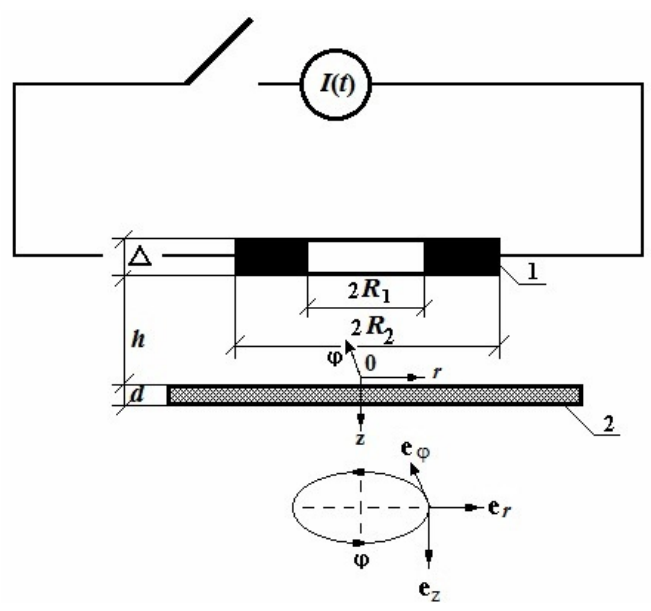

a

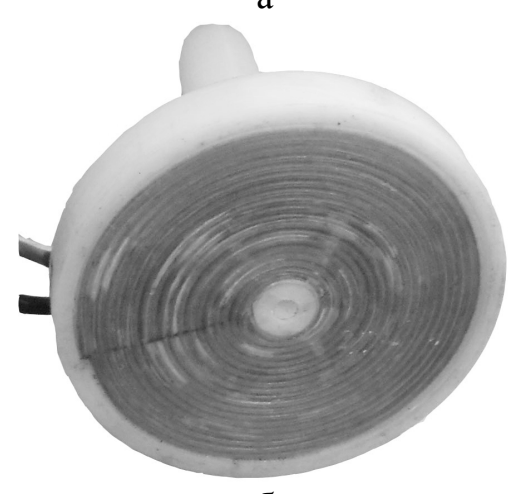

б

Fig.1. Flat-type circular multiturn solenoid for induction heating: a - the calculation model of the «inductor - workpiece»: $I(t)-\mathrm{AC}$ power supply; 1 - multiturn solenoid; 2 - flat-type parent sheet; $\mathrm{b}$ - a solenoid model version

Averaging by the spatial coordinates $\left\{z \in[0 ; d], r \in\left[0 ; R_{2}\right]\right\}$ the value of the induced current can be written in terms of the excitation signal phase

$$
\begin{aligned}
& \overline{I_{\varphi}(\varphi)}=\left(4 \cdot\left(I_{m} \cdot w\right) \cdot \frac{d}{\left(R_{2}-R_{1}\right)}\right) \int_{0}^{\infty} x \cdot f(x) \cdot e^{-x \frac{h}{d}} \times \\
& \times\left(1-J_{0}\left(x \frac{R_{2}}{d}\right)\right) \times \\
& \times \sum_{k=0}^{\infty} a(k) \cdot \frac{F_{k}\left(x, \beta_{k}\right)}{\Phi_{k}(x)} \cdot \frac{d j(\varphi)}{d \varphi} * e^{-\frac{\left(\beta_{k}^{2}+x^{2}\right)}{\omega \tau} \cdot \varphi} d x, \\
& \text { where } \quad \varphi=\omega \cdot t, f(x)=\frac{1}{x^{2}} \cdot \int_{x \cdot \frac{R_{1}}{d}}^{x \cdot \frac{R_{2}}{d}} y \cdot J_{1}(y) \cdot d y, \\
& a(k)= \begin{cases}0,5, & k=0 ; \\
1,0, & k \neq 0 ;\end{cases}
\end{aligned}
$$


$F_{k}(x)=\left(1-\cos \left(\beta_{k}\right)\right)+\frac{\beta_{k}}{x} \cdot \sin \left(\beta_{k}\right)$,

$\beta_{k}$ - roots of the equation:

$$
\begin{gathered}
\left(1-\left(\frac{\beta_{k}}{x}\right)^{2}\right) \cdot \sin \left(\beta_{k}\right)+2 \cdot\left(\frac{\beta_{k}}{x}\right) \cdot \cos \left(\beta_{k}\right)=0, \\
\Phi_{k}(x)=\cos \left(\beta_{k}\right) \cdot\left[x^{2}+2 x-\beta_{k}^{2}\right]- \\
-2 \cdot \beta_{k} \cdot \sin \left(\beta_{k}\right) \cdot[1+x] .
\end{gathered}
$$

The transformation ratio is determined as the ratio of the amplitudes of the exciting and induced current in a parent sheet in a circle of radius $-R$ (region: $r \leq R$ )

$$
\begin{gathered}
K(R, \varphi)=\frac{J_{\varphi \max }(R)}{I_{m}}=\left(\frac{4 \cdot d \cdot w}{\left(R_{2}-R_{1}\right)}\right) \times \\
\times \int_{0}^{\infty} f(x) \cdot x \cdot e^{-x \frac{h}{d}} \cdot\left(1-J_{0}\left(x \frac{R}{d}\right)\right) \times \\
\times\left.\sum_{k=0}^{\infty} a(k) \cdot \frac{F_{k}\left(x, \beta_{k}\right)}{\Phi_{k}(x)} \cdot\left(\cos \varphi^{*} e^{-\frac{\left(\beta_{k}^{2}+x^{2}\right)}{\omega \tau} \varphi}\right)\right|_{\max } \cdot d x .
\end{gathered}
$$

The dependence for heating temperature of the considered circular area of sheet metal during the time corresponding to the phase interval is $\Delta \varphi$

$$
\Delta T^{o}=\frac{1}{(M \cdot C \cdot \gamma \cdot d \cdot \omega)} \cdot \int_{0}^{\Delta \varphi}\left(\overline{I_{\varphi}(\varphi)}\right)^{2} \cdot d \varphi,
$$

where $M$ - plate weight, $M=\rho \cdot \pi \cdot R_{2}^{2} ; C$ - specific heat capacity of the plate metal.

Equations (1)-(3) are the ratio allowing to carry out all necessary numerical evaluations of the IH process characteristics in the «inductor - sheet workpiece» system.

\section{Numerical estimates}

Calculations are carried out for the following initial data: the number of turns in the inductor coil is $w=20$, its radial dimensions is $R_{1}=0,0025 \mathrm{~m}$ and $R_{2}=0,0225 \mathrm{~m}$ (the transverse coil dimension corresponding to the operating area is $40 \mathrm{~mm}$ ), the thickness of parent sheet is $d=0,001 \mathrm{~m}$, the gap clearance between the inductor surface and the workpiece is $h=0,001 \mathrm{~m}$, the conductivities of nonmagnetic steel and aluminum are correspondingly, $\gamma_{S t} \approx 0,4 \cdot 10^{7}(\mathrm{Ohm} \cdot \mathrm{m})^{-1}$ and $\gamma_{A l} \approx 3,75 \cdot 10^{7}(\mathrm{Ohm} \cdot \mathrm{m})^{-1}$, operating frequency range is $f \in[25000 ; 50000] \mathrm{Hz}$, the current amplitude in the inductor coil is $I_{m}=10 \div 15 \mathrm{~A}$.

Calculations were performed using a standard software package «Mathematica 5.1» according to the following algorithm.

1. By the form of the integrand $-f(x)$, which is the Fourier-Bessel way to distribute radially the initiated current in the inductor $-f(y)$, the approximate range of changing the variable of integration $-x$ is determined where $|f(x)|$ is different from zero, i.e., $x \in\left[0 ; x_{\max }\right]$. The adjustment of this interval of integration is accomplished for taking $x>x_{\max }$ a priori, by comparing the final calculation results. The allowed disalignment is $\sim 5 \div 10 \%$.

As numerical evaluation showed, for the accepted inductor geometry $\left(R_{1}=0,0025 \mathrm{~m}\right.$ and $R_{2}=0,0225$ $\mathrm{m})$ is taken $x \in[0 ; 0,8]$.

2. In the range of values $x \in\left[0 ; x_{\max }\right]$ the roots of the equation in the formula (1) $-\beta_{k}=\beta_{k}(x)$ are calculated for the values of the summation index $k=0,1,2,3 \ldots$

3. In general, the calculated dependence $\beta_{k}=\beta_{k}(x)$ can be approximated by a set of linear functions. As numerical evaluation showed, for the received inductor geometry the approximation by analytic dependence seems quite satisfying: $\beta_{k} \approx k \cdot \pi+\sqrt{2 \cdot x}$.

4. The obtained dependence $\beta_{k}=\beta_{k}(x)$ is applied in the integrands of calculating formulas $[13,14]$.

5. Improper integrals and sums of the series are calculated using the standard commands «NIntegrate» and «NSum».

6. The summation in the series is carried out for different numbers of harmonics. Their calculated number is considered to be sufficient if the increase of utmost value $\langle k\rangle$ does not lead to a result that differs from the previous one by more than $5 \div 10 \%$.

By summarizing the calculation results we can make the following conclusions.

Non-magnetic steel.

a) $f=25000 \mathrm{~Hz}$.

- Transformation ratio calculated by the formula (2) according to the transverse dimensions of the heated area would be $K \approx 15,9 \div 17,4$. 
- The sample should get warm for $\sim 4$ min up to the temperature $\sim 100{ }^{\circ} \mathrm{C}$ when the inductor current is $10 \mathrm{~A}$.

b) $f=50000 \mathrm{~Hz}$.

- Transformation ratio, depending on the transverse dimensions of the heated zone will be $K \approx 17,4 \div 18,3$.

- When the inductor current is $10 \mathrm{~A}$ the sample should get warm for $\sim 3$ min up to the temperature $\sim 100{ }^{\circ} \mathrm{C}$. With the current increase up to $\sim 15$ A the heating time goes down. If $f=25000 \mathrm{~Hz}$ the process takes less $\sim 2 \mathrm{~min}$. If $f=50000 \mathrm{~Hz}$ it takes less $\sim 1,5 \mathrm{~min}$.

The behavior of electromagnetic processes at different operating frequencies is illustrated by the graphs given in Fig. 2.

- Comparing the indexes of induction heating of steel samples shows that the increase in the fre-

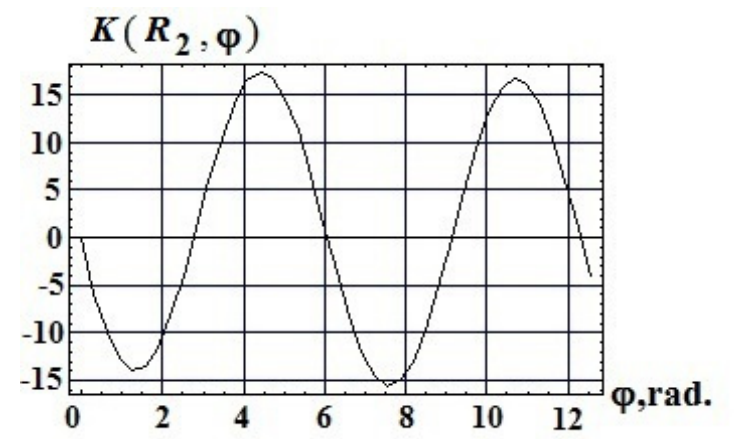

a

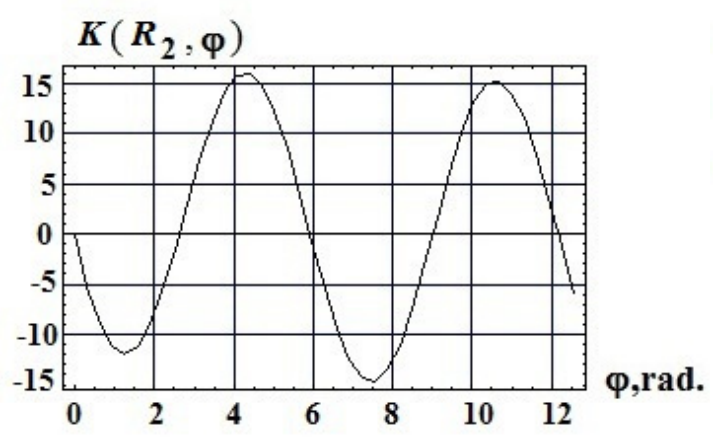

c quency of the excitation current from $50000 \mathrm{~Hz}$ to $25000 \mathrm{~Hz}$ is accompanied by the following effects. The transformation ratio increases by nearly $\sim 10 \%$ (from $15,9 \div 17,4$ to $19,5 \div 19,7$ ).

$-$

- The time of heating to the temperature of $100{ }^{\circ} \mathrm{C}$ falls by factor of 1,3 .

In general, increasing the current frequency in the inductor increases the efficiency of energy transformation from the source to the sheet metal and thus the heating efficiency.

From the electrodynamic point of view, it can be explained by decrease in the effective penetration depth in relation to the sheet thickness (from 1,6 to 1,1), that results in decreasing of scattering of electromagnetic energy used for the induction heating of the sample.

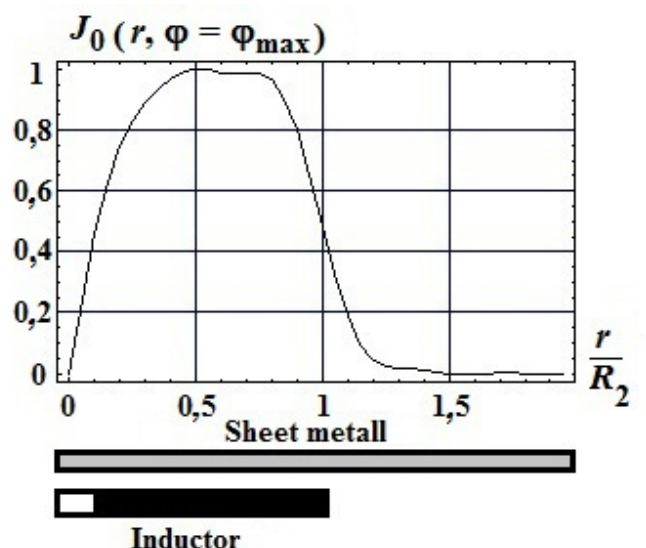

b

$$
J_{0}\left(r, \varphi=\varphi_{\max }\right)
$$

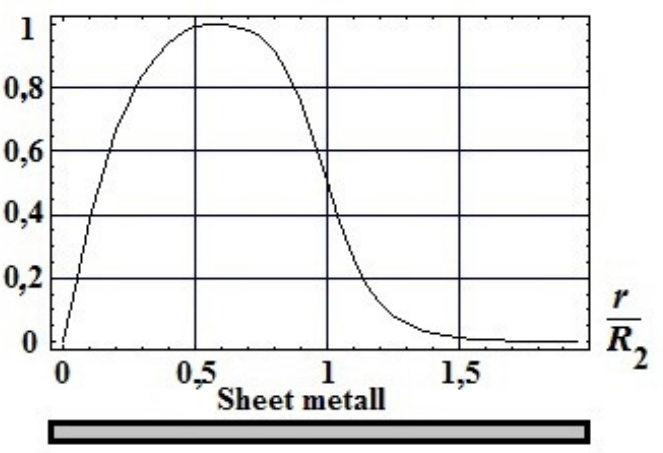

Inductor

d

Fig. 2. Dependencies of the main characteristics of electromagnetic processes in the steel samples, $\mathrm{a}$ - the current transformation ratio in a circular area of $R_{2}$ radius as a function of phase $(\varphi=2 \pi \cdot f \cdot t)$ with the frequency $f=25000 \mathrm{~Hz} ; \mathrm{b}$ - radial distribution of induced current density with the normalization to the maximum amplitude in the phase $\varphi_{\max }=4,39$ radius with the frequency $f=25000 \mathrm{~Hz} ; \mathrm{c}$ - the transformation ratio at the frequency $f=50000 \mathrm{~Hz} ; \mathrm{d}-$ radial distribution of induced current density at the frequency $f=50000 \mathrm{~Hz}$ 
Aluminum

a) $f=25000 \mathrm{~Hz}$.

- The transformation ratio depending on the transverse dimensions of the heated zone $\left(r \leq R_{2}\right.$ and $\left.r \leq 10 \cdot R_{2}\right)$ is $K \approx 19,5 \div 19,8$.

- The heating up to about $100^{\circ} \mathrm{C}$ at the inductor current $\sim 10$ A equals $\sim 14 \mathrm{~min}$.

b) $f=50000 \mathrm{~Hz}$.

- The transformation ratio depending on the transverse dimensions of the heated zone $\left(r \leq R_{2}\right.$ and $r \leq 10 \cdot R_{2}$ ) equals $K \approx 19,92 \div 19,98$.

- When the inductor current is $\sim 10$ A the sample should get heated for $\sim 11 \mathrm{~min}$ up to the temperature $\sim 100^{\circ} \mathrm{C}$.

When the current increases up to $\sim 15$ A the heating time falls. If $f=25000 \mathrm{~Hz}$ it takes less $6 \mathrm{~min}$. If $f=50000 \mathrm{~Hz}$ it takes less $\sim 5 \mathrm{~min}$.

Electromagnetic processes in time and space are shown in Fig. 3.
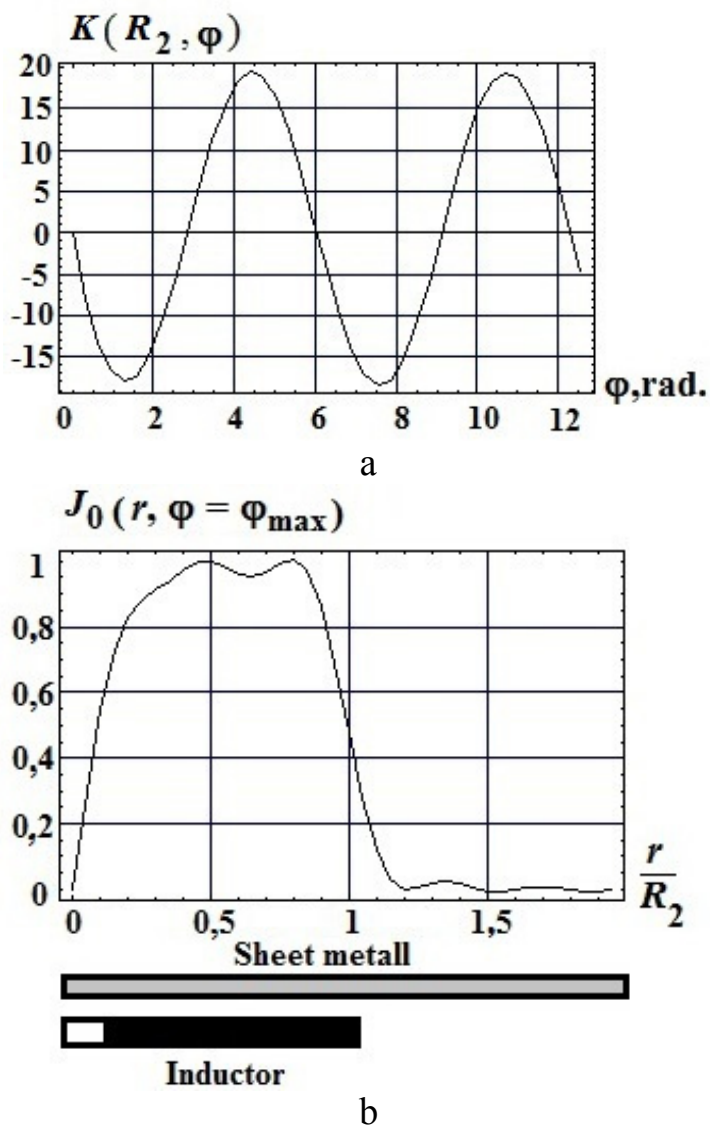

Fig. 3. Electromagnetic processes in aluminum at a frequency $f=25000 \mathrm{~Hz}$ : a - Current transformation ratio in a circular area of $\mathrm{R}_{2}$ radius as a function of phase $(\varphi=2 \pi \cdot f \cdot t)$; $b$ - the radial distribution of induced current density with the normalization to the maximum amplitude in a phase $\varphi_{\max }=4,39$ radius
Comparing the calculations results in the operating frequency range $[25000 ; 50000] \mathrm{Hz}$ of the current in the inductor to aluminum samples shows the following effects.

- Transformation ratio is almost unchangeable and corresponds to its maximum possible value, equal to the number of inductor turns.

- Transformation ratio independence on the time limit of the exciting current is explained by the fact that in the defined frequency range the ratio value of the effective depth of field penetration to the sheet thickness $(0,52 \div 0,36)$ corresponds to the almost total concentration of electromagnetic energy of the induced signal in the thickness of an aluminum sheet.

In general, although the increase of the current frequency in the inductor does not increase the efficiency of energy transformation processes from the source to an aluminum sheet, but the efficiency of its induction heating increases. So with $f=50000 \mathrm{~Hz}$ for receiving the same sample temperature it takes a factor of 1,27 less time than with the frequency $f=25000 \mathrm{~Hz}$.

The summary of the obtained results of IH processes evaluation allows to formulate some recommendations for choosing operating frequencies of the exciting current at $\mathrm{IH}$ nonmagnetic sheet metal.

1. It is efficient to operate in the frequency range, when the upper limit is set up by the electric conductivity of nonmagnetic metal of a heated sample, which allows raising the efficiency of energy transformation if the frequency increases, as well as the induction heating correspondingly while reducing the current amplitude in the inductor coil.

2. While choosing the operating frequency it is necessary to take into account not only the conversion efficiency of a drive signal into the induced one, but also to consider its effect on the temperature of the inductor coil, which is also determined by the skin effect, i.e., the displacement of the current flowing to the metal surface when the frequency of electromagnetic processes increases.

The current density in the inductor coil with the skin effect in this frequency range is about $20 \div 40 \mathrm{~A} / \mathrm{mm}^{2}$. In practice this means that when the system is in continuous operation the external coil cooling is required. 


\section{Conclusion}

The main results of the evaluation are the following:

1. The transformation ratio is defined in this system by the ratio of the effective penetration depth in the conductor and its thickness, which determines the degree of dispersion or concentration of electromagnetic energy in the considered metal part of a sheet sample.

2. For the steel samples with low conductivity the operating frequencies from the calculated range $f \in[25000 ; 50000] \mathrm{Hz}$ correspond to a certain growth of transformation ratio, as its maximum range lies in the field where $f_{\text {max-steel }} \approx$ $63000 \mathrm{~Hz}$.

3. The fall of transformation ratio value relative to the highest possible value while reducing the field size, where the induction process is examined (up to $\sim 10 \%$ ) occurs due to «spreading» of the linear density of the induced currents in the range of frequencies $f \in[25000 ; 50000]$.

4. For the aluminum samples with high values of specific conductivity the operating frequencies from the calculated range $f \in[25000 ; 50000] \mathrm{Hz}$ are sufficiently high, therefore:

- there is a very slight increase in the transformation ratio,

- there is nonessential «spreading» of the linear density of the induced current (substantially radial distribution is concentrated under the inductor coil) and as a result, there are rather small differences of the transformation coefficient values relative to the largest possible value with reducing the area where the induction is studied.

5. The estimated time of heating up to the temperature $\sim 100{ }^{\circ} \mathrm{C}$ with frequencies $\sim 25000 \div$ $50000 \mathrm{~Hz}$ and the current amplitude in the inductor $\sim 10 \div 15 \mathrm{~A}$ for thick sheet samples $\sim 1 \mathrm{~mm}$ makes up:

- 1,5 $\div 4 \mathrm{~min}$ - steel;

- $5 \div 14$ min - aluminum.

\section{References}

1. Benenson W. Hand book of Physics / W. Benenson, J.W. Harris, H. Stöcker, H. Lutz (Eds.) // Springer Science \& Business Media. - 2002. - P. 501-550.
2. Rudnev Valery Handbook of Induction Heating / Valery Rudnev, Don Loveless, Raymond L. Cook. Micah Black. - Michigan: Marcel Dekker AG, 2002. - 796 p.

3. Song Wang Single-Sided Electromagnetic Induction Heating Based on IGBT / Song Wang, Guangda Li, Xiaokun Li // Advances in Mechanical Engineering. - 2014. - P. 118. Article ID 503849.

4. Candeo A. Multiphysics modeling of induction hardening of ring gears for theaerospace industry / A. Candeo, C. Ducassy, P. Bocher, F. Dughiero // IEEE Transactions on Magnetics. - 2011. - Vol. 47. - P. 918921.

5. Zinn S. Elements of Induction Heating: Design, Control and Applications / S. Zinn, S.L. Semiatin. - Palao Alto, California: ASM International Year. - 1988. - $335 \mathrm{p}$.

6. Frank W. Curtis High Frequency Induction Heating - Lindsay Publications Inc. - 1987.

7. Welcome to BETAG Innovation [Electronic resource]. - 2015. - Available at: www.beulentechnik.com.

8. Belyy I.V. Electromagnetic Metal Forming Handbook / I.V. Belyy, S.M. Fertik, L.T. Khimenko, 1977. - Available at: http://www.mse.eng.ohiostate.edu / Daehn/ metalforminghb/index.html (accessed 04.11.10).

9. Batygin $\mathrm{Yu}$. V. Basic diagram and practical algorithm removing dents on the body of vehicle by the pulsed electromagnetic attraction / Yu. V. Batygin, A.V. Gnatov // International Journal Of Engineering Sciences \& Management. - 2015. - January-March. Vol. 5, Issue 1. - P. 47-51.

10. Bruni C. Effect of Temperature, Strain Rate and Fibre Orientation on the Plastic Flow Behaviour and Formability of AZ31 Magnesium Alloy / C. Bruni, A. Forcellese, F. Gabrielli, M. Simoncini // Journal of Materials Processing Technology. - 2010. Vol. 210. - P. 1354-1363.

11. Psyk V., Risch D., Kinsey B.L., Tekkayaa A.E., Kleiner M., Electromagnetic forming - A review / V. Psyk, D. Risch, B.L. Kinsey, A.E. Tekkayaa, M. Kleiner // Journal of Materials Processing Technology. - 2011. Vol. 211, Issue 5: 1 May. - P. 787-829.

12. Batygin Yu.V. Pulsed electromagnetic attraction of sheet metals - Fundamentals and perspective applications / Yu.V. Batygin, Sergey F. Golovashchenko, Andrey V. Gnatov // Journal of Materials Processing Technology. - 2013. - № 213 (3). - pp. 444-452. 
13. Batygin Yu. V. Pulsed electromagnetic attraction of nonmagnetic sheet metals / Yu. V. Batygin, Sergey F. Golovashchenko, Andrey V. Gnatov // Journal of Materials Processing Technology. - 2014. - Vol. 214, Issue 2. - P. 390-401.

\section{References}

1. Benenson W., Harris J.W., Stöcker H., Lutz H. (Eds.) Hand book of Physics, Springer Science \& Business Media, 2002.

2. Valery Rudnev, Don Loveless, Raymond L. Cook Micah Black Handbook of Induction Heating, Michigan, Marcel Dekker AG Publ., 2002. 796 p.

3. Song Wang, Guangda Li, and Xiaokun Li Single-Sided Electromagnetic Induction Heating Based on IGBT, Advances in Mechanical Engineering, 2014. pp. 1-18, Article ID 503849.

4. Candeo A., Ducassy C., Bocher P. and Dughiero F. Multiphysics modeling of induction hardening of ring gears for theaerospace industry, IEEE Transactions on Magnetics, 2011. Vol. 47, no. 5, pp. 918-921.

5. Zinn S. and Semiatin S.L. Elements of Induction Heating: Design, Control and Applications, Palao Alto, California, ASM International Year Publ., 1988. 335 p.

6. Frank W Curtis, High Frequency Induction Heating, Lindsay Publications Inc, 1987.

7. Welcome to BETAG Innovation. 2015. Available at: www.beulentechnik.com.

8. Belyy I.V., Fertik S.M., Khimenko L.T. Spravochnik po Magnitno-impulsnoy Obrabotke Metallov [Electromagnetic Metal Forming Handbook], 1977. Available at:
http://www.mse.eng.ohiostate.edu/_Daehn/ metalforminghb/index.html (accessed 04.11.10).

9. Batygin Yu. V., Gnatov A.V. Basic diagram and practical algorithm removing dents on the body of vehicle by the pulsed electromagnetic attraction. International Journal of Engineering Sciences \& Management, 2015. Vol. 5, Issue 1, January- March, pp. 47-51.

10. Bruni C., Forcellese A., Gabrielli F., Simoncini M. Effect of Temperature, Strain Rate and Fibre Orientation on the Plastic Flow Behaviour and Formability of AZ31 Magnesium Alloy, Journal of Materials Processing Technology. 2010. 210. pp. 13541363.

11. Psyk V., Risch D., Kinsey B.L., Tekkayaa A.E., Kleiner M. Electromagnetic forming A review, Journal of Materials Processing Technology, Elsevier Publ., 2011. Vol. 211, Issue 5: 1 May, pp. 787-829.

12. Batygin Yu. V., Golovashchenko S.F., Gnatov A.V. Pulsed electromagnetic attraction of sheet metals - Fundamentals and perspective applications. Journal of Materials Processing Technology, Elsevier Publ., 2013. Vol. 213 (3), pp. 444-452.

13. Batygin Yu. V., Golovashchenko S.F., Gnatov A.V. Pulsed electromagnetic attraction of nonmagnetic sheet metals, Journal of Materials Processing Technology, 2014. Vol. 214, Issue 2, pp. 390-401.

Рецензент: А.С. Полянский, профессор, д.т.н., ХНАДУ . 